\title{
Strategic Public Procurement: Facilitating Sustainable Development in Ukraine
}

\author{
Vesta Malolitneva ${ }^{1}$ and Ruslan Dzhabrailov ${ }^{2}$
}

\begin{abstract}
New benchmarks for world development were approved at the UN Summit in 2015, namely 17 Sustainable Development Goals. Ukraine, like other UN member states, has joined the global process of ensuring sustainable development. This requires conceptual changes in all spheres of life. Public procurement is considered as one of the most powerful tools for solving social, environmental and economic challenges facing the world. The article is dedicated to the role of sustainable public procurement and substantiation of ways of changing the conceptual approach to procurement in order to achieve the goals of sustainable development in Ukraine. Based on the analysis of foreign experience, it is proposed to change the approach to public procurement in Ukraine in such a way as to emphasize not only reduction of costs and saving of public funds but also the support of the long-term goals of the state.
\end{abstract}

Keywords: public procurement, sustainable development, sustainable public procurement, "borizontal" objectives, green public procurement, socially responsible public procurement.

\section{Introduction}

With the adoption in September 2015 in the framework of the 70th Session of the UN General Assembly of 17 Global Sustainable Development Goals by 2030, almost the whole world reaffirmed the need for more sustainable development. Ukraine, like other UN member states, joined the global process of sustainable development, which requires conceptual changes in all spheres of life. Such additional commitments by Ukraine are also confirmed by the European Union (hereinafter the EU)-Ukraine Association Agreement, one of the chapters of which is dedicated to the issue of sustainable development. At the moment, "business as usual" no longer has to be an option for the state, because our consumption of resources substantially exceeds resources availability on the planet (Forum for the Future, 2007; Fisher, 2013, 2). The society, the environment and the economy are under the influence of today's generation, which is the beneficiary of the past and responsible for future generations. At the same time, there may be a conflict of interest between today's and future generations, which cannot be solved with the help of only market mechanisms. Today, public procurement is considered as one of the means of ensuring the interests of future generations and promoting the goals of sustainable development, especially during times of economic crisis, when the threat of giving priority to short-term benefits is most urgent.

${ }^{1} \mathrm{PhD}$., senior researcher at the Institute of Economic and Legal Research of the National Academy of Sciences of Ukraine, Kyiv.

${ }^{2}$ Doctor of Law, deputy director at the Institute of Economic and Legal Research of the National Academy of Sciences of Ukraine, Kyiv. 


\section{Sustainable Development: Why Public Procurement?}

According to the World Bank, about $50-70 \%$ of national budgets are costs for public procurement. On average, the total public procurement reaches approximately $20 \%$ of GDP in countries of the Organization for Economic Co-operation and Development and 15\% in non-member countries (United Nations Department of Economic and Social Affairs 2008). According to individual estimates, public procurement makes one fifth of world GDP (United Nations Industrial Organization, 2017). Procurement volumes in Ukraine are also significant - almost $12 \%$ of GDP (VoxUkraine, 2018). This represents significant opportunities for improving the environment and quality of life by choosing appropriate goods, works and services, since all products and services have social, environmental and economic impacts throughout their life cycle. In addition, contracting authorities often act as key economic agents in markets with strong environmental and social impacts and have sufficient purchasing power to shape market trends (Tosoni, 2013, 41). Taking into account the significant role of public procurement, more and more countries in the world use them to implement, along with the functional purpose, strategic goals often referred to as "horizontal" or "secondary" goals in academic debates (Arrowsmith, 2010, 149-186; Arnould, 2004, 187197). One of the most common groups of strategic goals implemented through public procurement is the goals of sustainable development.

In Ukraine, public procurement is not considered as a strategic tool for achieving the country's long-term goals in various areas of Ukraine's government policy. Recently, the Ministry of Economic Development and Trade of Ukraine has presented a national report "The Sustainable Development Goals: Ukraine" (Ministry of Economic Development and Trade of Ukraine, 2017), which provides recommendations for the achievement of Global Goals where public procurement could play an important role. However, currently, one of the main indicators of the public procurement system efficiency in Ukraine is saving of public funds, which is calculated as the difference between expected value of goods and value of the winning bid. Weight of the price criterion was increased from $50 \%$ to $70 \%$ by main procurement procedures if other criteria are used to determine the most economically advantageous tender offer.

It should be noted that there are tendencies in Ukraine to develop green public procurement which is mostly stipulated by the obligations under the EU-Ukraine Association Agreement. However, the progress in this direction is quite slow, because Ukraine perceives public procurement mostly as a tool for efficient use of state funds but not achieving the goals of various policies. The Law of Ukraine "On Public Procurement" stipulates that technical, qualitative characteristics of the procurement subject should provide for application of environmental protection measures, and makes it possible to apply other criteria for evaluating tender proposals in addition to price. The list of criteria for evaluation of proposals set forth in Article 28 of the Law of Ukraine "On Public Procurement" is not exclusive for the selection of the winner. However, this is not enough, because the main principle of sustainable procurement is the relationship between the three components: environmental, social and economic. Furthermore, there are currently no incentives and additional flexible tools for implementing sustainable procurement, such as life cycle costing approach to procurement bid evaluation. In the 
context of limited public funds in Ukraine, the traditional one-dimensional approach adopted to public procurement is justified, however, it is only a tactical task for the near future and is not intended for a long-term perspective, nor does it take into account interests and assume any responsibility for future generations. However, the results of the country's activities cannot be regarded as successful if they bring only short-term benefits and have a negative medium- and long-term impact on society, environment or economy. A conceptual change in the approach to public procurement system is needed in order to achieve the sustainable development goals, which will consider not only the reduction of costs but also the achievement of the country's long-term goals.

Thus, the purpose of the article is to substantiate the ways of changing the conceptual framework for implementation of public procurement in Ukraine, which will ensure the achievement of the country's long-term goals, in particular the sustainable development goals.

\section{What is Sustainable Public Procurement?}

To date, given the limited budgets of countries and the need to reduce costs as well as the rational use of public funds, the procedure for public procurement has a special focus on. In this aspect, a traditional approach to public procurement has been formed that involves the behaviour of the country as an ordinary consumer, which will be guided by the highest quality at the lowest price. However, global challenges facing the whole world and the change in some countries in the attitudes of the society to the role of the state in the economy have shown that procurement can be used strategically, including for achievement of sustainable development covered by the concept of sustainable public procurement.

Sustainable procurement is defined as the processes of acquiring goods and services that meet user's needs, deliver long term value for money, maximise social and economic benefits and minimise damage to the environment and health (Forum for the Future, 2007). Sustainable procurement builds on the principles and good practices of "traditional" procurement and considers additional factors to maximize social, environmental and economic benefits for the procuring organization, its supply chain and society as a whole (United Nations Procurement Capacity Development Centre, Inited Nations Environment Programme, 2012).

Three pillars of sustainable development, in particular environmental, economic and social, are usually considered to have the same importance. However, there are approaches where the environmental component is recognized as the main and uncompromising element of sustainable development. The idea is that the social and economic components not only affect the environment but they cannot exist without it (ClientEarth, 2011). However, recognizing the interdependence of all three pillars of sustainable development, environmental, social and economic issues need not to be addressed separately. After all, for example, the environmental policy will have an economic and social impact, and vice versa. Thus, procurement, in which the choice is made for non-recyclable plastic products, has a negative impact not only on the environment but also on people in the future, for example, by contaminating the food chain (Choy and Drazen, 2013, 155-163). 
Therefore, we should agree with the position that if environmental aspects are not taken into consideration when formulating and implementing policies governing economic activity and other forms of social organization, a development model that can be environmentally sustainable in the long run is impossible. In turn, environmental sustainability should also be considered in the context of increasing interaction between goals of public policy aimed at protecting the environment, economic growth and social development (ClientEarth, 2011). After analysing experience of foreign countries in implementation of sustainable procurement, the most common types of procurement that are consistent with the three components of sustainable development can be identified. The environmental component - green procurement, energy efficient procurement, circular procurement for a circular economy; the social component socially responsible procurement; the economic component - procurement for innovations, procurement for development of fair trade, etc. However, it should be noted again that the goals achieved through these procurements are interconnected and interdependent united under the general concept or an umbrella term of "sustainable procurement". That is, sustainable procurement is a peculiar mechanism for optimal integration and implementation of horizontal goals of environmental, social and economic development in public procurement, along with the main goal (the highest quality at a lower price). At the same time, sustainable procurement contributes to overcoming the potential conflict between these goals, which are often pointed out in scientific literature (Glas, Schaupp and Essing, 2017, 580-581), for example, cost savings and environmental protection. It should be noted that achievement of sustainable development goals can greatly contribute to the goal of more rational use of public funds in the long run. Simply, these costs or funds are "external consequences" that are not taken into account by relevant contracting authority, and are redistributed to other government organizations. For example, procurement of low quality products with harmful additives will lead to negative consequences for people's health, which entails additional public costs for the public health body, and can generally take wider economic consequences - reducing labour productivity due to illness and health of the nation. These costs, as a rule, are not included into the procurement price by contracting authority. Non-sustainable procurement has consequences for the cost of society in a form of social and environmental damage and, consequently, economic damage. Sustainable procurement makes it possible to reconcile and balance private and public interests when the interests of bidders and the state as consumer of goods, works and services are met, but at the same time they meet and pursue public interests, in particular interests of taxpayers whose money are largely accumulated in the state budget.

\section{Foreign Experience of Strategic Use of Public Procurement to Achieve the Sustainable Development Goals}

Taking into account Ukraine's commitments under the EU-Ukraine Association Agreement, including in the field of public procurement, it is important to analyse the experience of the EU, which pursues an active policy of introducing sustainable public procurement, and has created a flexible legal framework and understanding of the need for a conceptual change to the approach to public procurement. The EU public 
procurements amount to approximately 14\% of the EU's GDP annually. Given the significant economic weight of procurement, the EU is pursuing an active policy of strategic use of procurement to achieve not only the best value for money (European Commission, 2017). The ultimate goal is to assure taxpayers that procurement complies with environmental, social and labour standards, that more sustainable goods are procured with the use of their money and a sustainable development policy is implemented, thereby triggering changes in the behaviour of market, stakeholders and society as a whole (European Commission, 2017, 219-223). The EU has launched the reform in 2011 from the European Commission's Green Paper on the modernisation of EU public procurement policy - Towards a more efficient European Procurement Market (European Commission, 2011). This document emphasizes the key role of public procurement in solving current problems. To this end, the need for modernization of existing tools and tools for using procurement in addressing problems in the political, social and economic context is determined. The Green Paper also says about additional procurement goals that will allow wider use of public procurement to support general public goals, including environmental protection, innovation development, etc. In addition, the European Commission refers to the Europe 2020 Strategy, which defines three driving factors for economic development: 1) developing an economy based on knowledge and innovation; 2) promoting a more resource efficient, greener and more competitive economy; 3) fostering high-employment economy (European Commission, 2010). In accordance with the new EU Public Procurement Directives (European Parliament and Council of the EU, 2014), procurement has an important role to play in achieving these goals. Thus, among the key initiatives of the Strategy, the Innovation Union has been identified with clear goals and benchmarks. In particular, formation of the Innovation Union is aimed at improving quality of life and creating new jobs, promoting empowerment of citizens through introduction and dissemination of innovations, and improving the state of the environment. In this process public procurement plays a key role, through which the EU member states stimulate the demand for high-tech products. Moreover, the role of public procurement in the development of fair trade, which is considered by the EU as an integral part of sustainable development, remains important (CTA Brussels Office, 2008). Procurement can help achieve the main goal of fair trade, namely: to ensure that producers receive the price for their goods which reflects the adequate return of contribution of their abilities, labour and resources. In addition, by supporting marginalized producers and workers through fair trade, the state can show its commitment to sustainable development (Library of the European Parliament, 2012).

Significant attention in the EU is given to green public procurement. The third updated version of the Buying Green saw the world in 2016, in which several new green public procurement criteria were developed to facilitate inclusion of green requirements in tender documentation (European Commission, 2016). The EU energy efficiency plan also recognizes public procurement as one of the main means to achieve energy efficiency goals (European Commission, 2011). The EU Energy Efficiency Directive sets requirements for customers to procure only high energy efficiency products, services (European Commission, 2012). In addition, the EU also contributes to implementation of socially responsible public procurement (European Commission, 2011). 
The need for public procurement has been also recognized in the EU Sustainable Consumption and Production and Sustainable Industrial Policy Action Plan (European Commission, 2008). In this aspect, interesting experience is the development of circular economy in the EU, which assumes that the value of goods, materials and resources is kept in the economy for as long as possible and that waste generation is reduced (Nordic Council of Ministers, 2017), which implies economic growth, given the limited natural resources and energy. A key role in the development of such economy plays public procurement (Witjes and Lozano, 2016, 37-44). The aim of circular procurement is to ensure that goods or materials at the end of their service life are reused in a new cycle. Such procurement should play an important role in achieving the Sustainable Development Goals 2030, in particular Goal 12 - responsible consumption and production, which amongst the objectives determines the development of sustainable public procurement (United Nations, 2015). The development of circular economy, for example, involves changing the conventional approach to procurement, which is based not on the model of sales of goods, but on the service-oriented model. Often there is a need not in a very particular unit, but in a very function that provides this unit. This approach allows you to meet the needs of consumers with the fewest units, thereby reducing negative impact on the environment. For example, in 2013, the Bremen's Senate Department for Environment, Construction and Transport was able to reduce its $\mathrm{CO} 2$ emissions related to business trips and reduce costs by replacing fleet with membership in a local car sharing service. Prior to this, the Department had owned 11 cars, but their use was low - less than three hours a day. With transition to online car sharing services, Bremen currently has access to more flexible and efficient transportation routes, including electric vehicles, which saves money on maintenance, parking, etc. (European Commission, 2017).

A significant role in implementation of sustainable procurement and ensuring their coexistence with the goal of the development of a single EU market is played by the jurisprudence of the Court of Justice of the EU, e.g. Beentjes (Case 31/87) Concordia bus Finland (case C-513/99) and EVN/Wienstrom (Case C-448/01). For example, the necessary steps towards sustainable procurement were made in Concordia bus Finland. The European Commission had long argued that contracting authorities could use contract award criteria relating to environmental characteristics of the goods works or services only if they conferred a direct economic advantage upon the contracting authority. In the case Concordia bus Finland, in the context of a public contract for the provision of urban bus transport services, the question was whether the contracting authority could include environmental concerns (noise and pollution reduction) amongst award criteria. The Court's decision was based on the principle that award criteria need not necessarily be of a pure economic nature. Thus, with its judgment the Court confirmed that environmental considerations may be included in award criteria and laid down conditions under which such criteria may be used.

In May 2016, Ukraine became a full member of the World Trade Organization (WTO) Agreement on Public Procurement, within which the issues of the need for the development of sustainable procurement are increasingly being raised. Although the Agreement itself does not directly determine the principles for implementation of sustainable procurement, there is, however, a Work Program on sustainable procurement 
under which the activities of the WTO Public Procurement Committee are being pursued with a view to systematically improving the text of the Agreement (WTO, 2012). This program examines the following issues: 1) the purpose of sustainable procurement; 2) the ways in which the concept of sustainable procurement is integrated into national procurement policies; 3) the ways in which sustainable procurement can be carried out in accordance with the best value for money principle; and 4) the ways in which sustainable procurement can be made in accordance with international trade commitments.

Furthermore, the revised Model Law on Public Procurement of the United Nations Commission on International Trade Law of 2011, unlike the previous of 1994, contains a new concept of socio-economic policies that means environmental, social, economic and other policies of the country authorized or required by the procurement regulations or other provisions of law of this country to be taken into account by the procuring entity in the procurement proceedings (United Nations Commission on International Trade Law, 2014).

Therefore, we can conclude that there is a broad tendency towards the strategic use of public procurement, in particular achievement of sustainable development goals not only at the national levels of individual countries but also within the framework of international trade regimes. Thus, the focus of discussions on sustainable procurement should be on how to implement them in order not to violate requirements on competition and non-discrimination which is the subject of academic debate, and no longer on whether public procurement is possible and necessary at all (Weller and Pritchard, 2013, 59). The means of introduction and implementation of sustainable public procurement within the specified international trade regimes is worth a particular attention, but this issued is not covered by this article and will be the subject of a further study.

\section{Conclusions and Suggestions for Ukraine}

Conceptualization of sustainable development in Ukraine should promote the use of public procurement strategically, not only as a means for efficient and rational use of public funds, which requires a change in the approach to the system of public procurement. To this end, the country's purchasing power should be recognized as a means to achieve such goals.

Public sector has commitments to use public funds taking into account the longterm impact of each procurement, without endangering public health, a safe environment and opportunities for professional self-actuating. A change is needed not only for the conceptual approach to procurements, in particular their strategic use, but also for strategic thinking. This involves substantiation of the need for procurement in general and considering possibility of using leasing, sharing, etc., i.e., orientation to services instead of goods.

To make sustainable development an integral part of the procurement process in Ukraine, procurement power should change the conceptual approach from "making things better" to "making better things" (Fisher, 2013, 2) and optimally combine the concepts from "how to buy" to "what to buy" (Weller, 2013, 55-59), which provides for satisfaction of not only functional goals, but also an aspiration to satisfy the objectives 
that are implemented within the respective directions of the country's government policy, in particular, sustainable development.

Adoption of a comprehensive document on implementation of horizontal goals in public procurement is proposed, in particular sustainable development - the Concept of Strategic Use of Public Procurement of Ukraine, which should set the necessary vector for changing the approach to public procurement and become the basis for their inclusion in the forecasts and programs of social and economic development.

\section{References}

Arnould, J. (2004). Secondary policies in public procurement: the innovations of the new Directives. Public Procurement Law Review, 4: 187-197.

Arrowsmith, S. (2010). Horizontal policies in public procurement: a taxonomy. Journal of public procurement, 10 (2): 149-186.

Beentjes BV v. Netherlands (Case 31/87). Judgment of the Court of 20 September 1988. Available at : https://eur-lex.europa.eu/legal-content/EN/TXT/?uri=CELEX\%3A61987CJ003 (accessed February 10, 2018).

Choy, C.A. Drazen, J.C. (2013). Plastic for dinner? Observations of frequent debris ingestion by pelagic predatory fishes from the central North Pacific. Marine Ecology Progress Series, 485: 155-163.

ClientEarth (2011). Sustainable Development as a Key Policy Objective of the European Union. Identifying Opportunities for Sustainable Public Procurement. Available at: https://www.documents.clientearth.org/wpcontent/uploads/library/2011-10-01-briefing-no.1-sustainable-development-as-a-key-policyobjective-of-the-european-union-ce-en.pdf (accessed January 10, 2018).

Concordia Bus Finland Oy Ab v Helsinki Kaupunki and HKL-Bussiliikenne (Case C-513/99). Judgment of the Court of 17 September 2002. Available at: http://curia.europa.eu/juris/liste.jsf?language $=$ en\&num $=C-513 / 99$ (accessed February 10, 2018).

CTA Brussels Office (2008). Does Fair Trade contribute to sustainable development? Available at: https://brusselsbriefings.files.wordpress.com/2012/10/br-5-reader-br-5-fair-trade-eng.pdf (accessed February 01, 2018).

European Commission (2008). Communication to the European Parliament, the Council, the European Economic and Social Committee and the Committee of the Regions on the Sustainable Consumption and Production and Sustainable Industrial Policy Action Plan. COM/2008/0397 final. Available at: https://eur-lex.europa.eu/legal-content/EN/TXT/?uri=CELEX:52008DC0397 (accessed December 20, 2018).

European Commission (2010). Europe 2020 A strategy for smart, sustainable and inclusive growth. COM(2010) 2020 final. Available at: https://eur-lex.europa.eu/legalcontent/en/ALL/?uri=CELEX\%3A52010DC2020 (accessed February 14, 2018).

European Commission (2011). Communication from the Commission to the European Parliament, the Council, the European Economic and Social Committee and the Committee of the Regions Energy Efficiency Plan. COM/2011/0109 final. Available at: http://eur-lex.europa.eu/legalcontent/EN/TXT/?qid=1407839592178\&uri=CELEX:52011DC0109 (accessed January 13, 2018).

European Commission (2011). Communication from the Commission to the European Parliament, the Council, the European Economic and Social Committee and the Committee of the Regions on the Sustainable Consumption and Production and Sustainable Industrial Policy Action Plan. COM/2008/0397 final. Available at: http://eur-lex.europa.eu/legal-content/EN/TXT/?uri=CELEX:52008DC0397 (accessed February 13, 2018).

European Commission (2011). Green paper on the modernisation of EU public procurement policy Towards a more efficient European Procurement Market. COM/2011/0015 final. Available at: http://eurlex.europa.eu/legal-content/EN/TXT/?uri=COM:2011:0015:FIN (accessed January 14, 2018).

European Commission (2016). Buying green! (3rd edition). Available at: http://ec.europa.eu/environment/gpp/pdf/Buying-Green-Handbook-3rd-Edition.pdf (accessed February 10, 2018). 
European Commission (2017). Strategic Public Procurement: Facilitating Green, Inclusive and Innovative Growth. European Procurement and Public Private Partnership Law Review, 12 (3): 219-223 (accessed December 18, 2018).

European Commission (2017). Communication from the Commission to the European Parliamnet, the Council, the European Economic and Social Committee and Committee of the Regions Making Public Procurement work in and for Europe. COM/2017/0572 final. Available at: http://eurlex.europa.eu/legal-content/EN/TXT/?uri=COM:2017:572:FIN (accessed February 02, 2018).

European Commission (2017). Communication from the Commission to the European Parliament, the Council, the European Economic and Social Committee and the Committee of the regions Closing the loop - An EU action plan for the Circular Economy. COM/2015/0614 final. Available at: https://eur-lex.europa.eu/legal-content/EN/TXT/?uri=CELEX\%3A52015DC0614 (accessed February 02, 2019).

European Parliament and Council of the EU (2014). Directive 2014/24/EU of the European Parliament and of the Council On public procurement and repealing Directive 2004/18/EC. Available at: https://eur-lex.europa.eu/legal-content/EN/TXT/?uri=celex\%3A32014L0024 (accessed September 15, 2018).

European Parliament and Council of the EU (2014). Directive 2014/25/EU of the European Parliament and of the Council On procurement by entities operating in the water, energy, transport and postal services sectors and repealing Directive 2004/17/EC. Available at: https://eur-lex.europa.eu/legalcontent/EN/TXT/?uri=celex\%3A32014L0024 (accessed September 15, 2018).

European Parliament and Council of the EU (2012). Directive 2012/27/EU of the European Parliament and of the Council of 25 October 2012 on energy efficiency, amending Directives 2009/125/EC and 2010/30/EU and repealing Directives 2004/8/EC and 2006/32/EC. Available at: http://eurlex.europa.eu/legal-content/EN/TXT/?uri=CELEX\%3A32012L0027 (accessed September 17, 2018).

EVN AG and Wienstorm GmbH v Austria (Case C-448/01). Judgment of the Court of 4 December 2003. Available at : http://curia.europa.eu/juris/liste.jsf?language $=$ en\&num $=c-448 / 01 \quad$ (accessed October 10, 2018).

Fisher, E. (2013). The power of purchase: addressing sustainability through public procurement. European Procurement \& Public Private Partnership Law Review, 8 (1): 2-7.

Forum for the Future (2007). Buying a Better World: Sustainable Public Procurement. Available at: http://eprints.uwe.ac.uk/23414/1/buying-better-world.pdf (accessed November 20, 2018).

Glas, A. Schaupp, M. Essing, M. (2017). An organizational perspective on the implementation of strategic goals in public procurement. Journal of Public Procurement, 17 (4) : 572-605.

Library of the European Parliament (2012). Fair trade in public procureent in the EU. Available at: http://www.europarl.europa.eu/RegData/bibliotheque/briefing/2012/120334/LDM BRI(2012) 120334 REV1 EN.pdf (accessed November 01, 2018).

Ministry of Economic development and Trade of Ukraine (2017). Sustainable Development Goals: Ukraine 2017 National Baseline Report. Available at : http://www.me.gov.ua/Documents/Download?id=22e86f94-a9dd-421e-adcb-e38748a4b7cb (accessed February 10, 2019).

Nordic Council of Ministers (2017). Circular Public Procurement in the Nordic Countries. Available at: http://norden.diva-portal.org/smash/get/diva2:1092366/FULLTEXT01.pdf. (accessed January 12, 2019).

Tosoni, L. (2013). The impact of the Revised WTO Government Procurement Agreement on the EU Procurement Rules from Sustainability Perspective. European Procurement \& Public Private Partnership Law Review, 8 (1): 41-48.

United Nations (2015). Goal 12. Ensure sustainable consumption and production patterns. Available at: https://www.un.org/sustainabledevelopment/sustainable-consumption-production/ (accessed December 10, 2018).

United Nations Department of Economic and Social Affairs (2008). Public procurement as a tool for promoting more sustainable consumption and production patterns: Sustainable development. Available at: https://sustainabledevelopment.un.org/content/documents/no5.pdf (accessed November 15, 2018). 
United Nations Procurement Capacity Development Centre, United Nations Environment Programme (2012). Sustainable Public Procurement. Available at: https://europa.eu/capacity4dev/file/11429/download?token=3rKamM6J (accessed December 10, 2018).

United Nations Commission on International Trade Law (2014). On Public Procurement: UNCITRAL Model Law. Available at : https://www.uncitral.org/pdf/english/texts/procurem/mlprocurement-2011/2011-Model-Law-on-Public-Procurement-e.pdf (accessed January 14, 2019).

United Nations Industrial Organization (2017). The role of public procurement policy in driving industrial development. Available at: https://www.unido.org/sites/default/files/2017-07/WP 8 FINAL 0.pdf (accessed February 19, 2019).

VoxUkraine (2018). Faktchek: yakyh pomylok prypuskayutsia avtory zakonoproektu "Kupuy ukrayinske" vid VoxUkraine. Available at: https://prozorro.gov.ua/news/faktchek-yakih-pomilokpripuskayutsya-avtori-zakonoproektu-kupuj-ukrayinske-vid-voxukraine [in Ukrainian] (accessed January 12, 2019).

Weller, C. Pritchard, J. (2013). Evolving CJEU Jurisprudence: Balancing Sustainability Considerations with the Requirements of the Internal Market. European Procurement \& Public Private Partnership, 8 (1): 5559 .

Witjes, S. Lozano, R. (2016). Towards more Circular Economy: Proposing a framework linking sustainable public procurement and sustainable business models. Resources, Conservation and Recycling, 112: 37-44.

WTO (2012). Annex E Decision of the Committee on governmemt procurement on a Work programme on sustainable procurement of 30 March 2012. Available at https://www.wto.org/english/tratop_e/gproc e/annexe e.pdf (accessed January 14, 2018). 